\title{
Russian language as a factor of soft power in cross-cultural communication: overcoming the crisis
}

\author{
Natalia A. Orekhovskaya - Elena I. Zamaraeva - Evgeniya V. Shikh - Alexander A. \\ Galushkin - Raisa I. Platonova - Alfia M. Ishmuradova
}

DOI: 10.18355/XL.2019.12.04.13

\begin{abstract}
The relevance of the work is determined by the need for a theoretical understanding of the problem of cultural interaction in the modern world. The process of globalization, which is underway, leads to the expansion of interrelationships and interdependencies of different peoples, including the problem of learning the specifics of cultures in the context of building an efficient local and global dialog based on the soft power policy. The purpose of the article is to analyze the crisis of the soft power policy in the spread of the Russian language as the most important tool of ethnic self-preservation. The methodological basis of the study consists of theoretical methods: the synthesis method is applied to study the problematic area of interaction between language and culture, in particular when considering the soft power policy. The combination of descriptive, comparative, and historical methods, as well as methods of classification and analytical reading, contributed to the formation of the author's understanding of the problem. The article presents the author's study of the soft power policy in the Russian education system. It discusses the signs of a crisis in the implementation of the soft power policy that has manifested themselves, on the one hand, through the changes of the main state documents regulating the education process, and on the other hand, the real results of the Russian language study are revealed. Upon analysis, the authors have identified and formulated a number of contradictions in the practice of the Russian language teaching in terms of the soft power policy application and also have come to the conclusion that, to overcome the crisis in the Russian language teaching, some viable options should be taken into account such as strong intellectual potential, experience and traditions of the national school.
\end{abstract}

Key words: Russian language, intellectual culture, cross-cultural communication, globalization, soft power policy

\section{Introduction}

A pivotal challenge of our time is the conflict between the growing globalization and the so-called glocalization. A number of serious challenges facing humanity today social, political, economic, environmental and many others - can be overcome only by joint efforts of different peoples (Nikiforova, Ignatiev, 2016; Geng, 2017; Sum, Kwon, 2018; Simsek, Elciyar, Kizilhan, 2019). However, the trend towards globalization simultaneously entails the desire of each individual nation for cultural self-determination, the national identity affirmation, and the preservation of its cultural values (Kolodeznikov, Kolodeznikova, 2016; Kamalova, Zakirova, 2017; Kuzina, 2018; Gonulal, 2019). Numerous ethnic and religious conflicts, as well as nationalistic sentiments in the modern world, are often dictated by the emphatic reluctance to change cultural codes and traditional value paradigms (Pöhler et al., 2017; Korkmaz, Güneyli, 2017).

Over the past twenty years, no major language on Earth has lost its position as rapidly as the Russian language. At the beginning of the XX century, there were about 150 million Russian speakers. They were mostly the Russian Empire citizens. Geographically, the spread of the language almost fully matched the Russian borders. Until the collapse of the Soviet Union, the number of Russian speakers increased to

XLinguae, Volume 12, Issue 4, October 2019, ISSN 1337-8384, eISSN 2453-711X 
350 million people, of which 286 million lived in the USSR (Bovt, 2019). Nevertheless, the main negative trend - the decreasing number of native speakers and users of the Russian language - has not yet been overcome. If the current negative trend of the Russian language territory "shrinkage" will continue in the next decade and a half, then presumably by 2025 the number of Russian speakers in different countries of the world will decrease to about 150-152 million people, i.e., the language will "retreat" to the position of the early twentieth century. In the Russian Federation, the number of Russian speakers may drop to no more than 110 million people only due to the degradation of the level of its knowledge (Uzun, 2018; Bovt, 2019). One of the reasons for the above is that the level of proficiency in Russian as the state language of the Russian Federation among the younger generation is already decreasing along with the narrowing of the sphere of its functioning as a means of interethnic communication. We should not forget about such deplorable facts as the distortion - often as a result of illiteracy - of the Russian literary language norms in the speech of politicians, civil servants, as well as cultural, television and radio workers' community. As a result, in 10-15 years, the Russian language will face the risk of falling behind such languages as French, Urdu, Arabic, Portuguese and Bengali in terms of popularity in the world.

\section{Methodological Framework}

The methodological basis of the study consists of such theoretical methods as the synthesis method applied to study the problematic area of interaction between language and culture, in particular when considering the theories of linguistic relativity and cultural determinism.

The combination of descriptive, comparative, and historical methods, as well as methods of classification and analytical reading, contributed to the formation of the author's understanding of the problems under study.

Analytical and system methods were applied in the process of studying culture and revealing its specific features as a communication system.

The analysis of different approaches to understanding the mentality was carried out using the generalization and concretization methods.

The formalization method helped define the key concepts of this study and interpret various concepts and theories.

The ideas and concepts about language and culture were analyzed using the dialectical method. The study of the culture's symbolic nature and semiotic concepts by Yu.M. Lotman (1998) actualized the semiotic approach and hermeneutical method.

Cultural and hermeneutical approaches are no less important in the study of the cultural identity formation process in the context of cross-cultural communications.

The use of the system method enabled a holistic and comprehensive study of language as a form of cultural existence. The method of cultural analysis and synthesis is applied to study the dialogic nature of culture.

The historical method was applied to trace the development of approaches to understanding language, culture, and communication.

The theoretical material on the research topic was analyzed using the system-based analytical method.

\subsection{Operationalization of Concepts}

The term "cross-cultural communication" first appeared in the 1950s in the works of E.T. Hall (1989), who treats culture as communication. However, the fundamental works of M.M. Bakhtin (1986), Yu.M. Lotman (1998), B.C. Bibler (1986) laid the foundations for the modern understanding of cross-cultural communication.

Cross-cultural communication can be both an important factor contributing to the development of cooperation and an intractable challenge in the implementation of 
certain projects, major social, economic, political, environmental, and other international initiatives and efforts.

The relevance of cross-cultural communication issues is manifested also through the fact that in the context of globalization, almost all countries seeking to take their special and rightful place in the global community are involved in the process of cross-cultural communication. This problem received particular attention in the twentieth century, once it became clear that many urgent challenges could not be overcome without the involvement of a wide range of stakeholders, representatives of different countries, cultures, and traditions. Cross-cultural communications are directly related to the processes taking place also in the field of cultural exchange. The dialog of cultures is a prerequisite for the development of communication, as well as a vivid example of its implementation.

Cross-cultural communication is a complex and multifaceted phenomenon, which includes a variety of areas and forms of communication between individuals, groups, and states belonging to different cultures.

Experience shows that culture has a particular role in the implementation of geopolitical strategies in many countries. The place and authority of states on the world arena are determined not only by their political, economic weight, and military power but also by the cultural, spiritual, and intellectual potential characterizing the country in the world community. It is a culture that possesses the unique resources associated with the formation of a positive image of the people and the country, which ultimately helps overcome political problems.

Nowadays, along with the traditional mechanisms of influence on other countries, the concept of soft power is widely used in foreign affairs policy, introduced into the political theory and practice by J. Nye (2004) at the end of the XX century.

Russia, which has a colossal cultural heritage, also uses this potential to strengthen its own positions in the world and in the post-Soviet space. For Russia, the soft power policy is a fairly new instrument for the harmonious promotion of national interests, therefore, the tools for the implementation of the soft power policy have not yet been sufficiently developed in many respects, although this concept was included in the 2013 Foreign Policy Concept of the Russian Federation and in the subsequent strategic documents (Lebedeva, 2017). However, even before the concept of soft power was introduced, the USSR accumulated vast experience of using the attractiveness of its values, lifestyle and cultural achievements, where the soft power capabilities enjoyed a broad economic and military support of fraternal countries, political parties and national liberation movements (Rusakova, Nosova, 2015).

One of the conditions for strengthening modern Russia's authority is the promotion of the Russian cultural heritage abroad, as well as the preservation and strengthening of the Russian-speaking space along Russian borders (Filimonov, 2012). The key element of soft power is the Russian language as a means of cross-ethnic communication across the vast territory of the former Soviet Union and the countries of the Eastern Bloc. By the end of the XX century (in 1990, the year before the collapse of the USSR), the number of Russian speakers in the world was 312 million people, which was the all-time peak (Arefyev, 2017). However, in the 25 years since the collapse of the USSR and the formation of new sovereign states in the post-Soviet space, the number of Russian speakers has decreased significantly.

The world's major powers have a different vision of priorities in conceptual approaches to soft power. Great Britain focuses on the promotion of Anglo-Saxon political values; Germany - on the promotion of the German language and culture, inter alia, through Goethe Institutes; Italy - on the promotion of cultural and historical values; China - on the development of non-violent influence instruments and the protection of national cultural safety from other international soft power actors competing with China, inter alia, through Confucius Institutes; the United

XLinguae, Volume 12, Issue 4, October 2019, ISSN 1337-8384, eISSN 2453-711X 
States - on the promotion of American political and economic values; and the European Union - on the promotion of European social and cultural values (Gorlova, Bychkova, 2019). The global ranking of soft power takes into account such indicators as the integrity or degree of integration of the nation and its culture, global integration and image, which includes migration flows, tourism, the country's attractiveness, culture, the number of Olympic medals, and legitimate political values having unconditional moral authority. According to the soft power ranking, Russia ranks 10th, falling behind the USA, France, Germany, Great Britain, Canada, Italy, Japan, China, and India (Gorlova, Bychkova, 2019).

According to the Country Brand Index published by Future Brand, an international consulting firm, Brazil ranks 28th, India - 42d, South Africa - 43rd, China - 66th, and Russia - 83rd among 118 countries (Yashkova, 2015). It is commonly known that Brazil implements the soft power concept through charm offensive, putting a premium on the attractiveness and friendliness of modern Brazilian culture and the harmonious development of all racial and ethnic groups. Implementing the concept of soft power, India relies on its rich national culture and unique Bollywood, South Africa - on sports achievements and "breathtaking" landscapes, China - on its great cultural heritage, which is promoted through more than 850 Confucius Institutes in various countries, designed to help residents of foreign countries "better understand China".

However, on the back of the aggravating international geo-economic, geopolitical and geocultural competition attempts to impose hegemony by the Western world and Western civilization led by the United States, and the natural difficulties of modernization transformations, the soft power policy pursued by the BRICS countries face inevitable problems and difficulties. This is true also for various kinds of ratings that affect both the minds of the general public and the political, scientific, and cultural elites.

\subsection{Analyzing crisis signs in the implementation of the soft power policy in the teaching of national languages}

The first step in the application of the soft power policy for the preservation and promotion of the Russian language should certainly be the development of domestic language policy. Russian education of the last decade pursues the task, inter alia, to develop cross-cultural communication skills.

The Federal Law On Education in the Russian Federation No. 273-FL of 29 December 2012 as amended in 2018 contains the following language: "The educational content should promote mutual understanding and cooperation between people and peoples regardless of race, national, ethnic, religious and social affiliation, and take into account the diversity of worldviews" (Federal law "on education in the Russian Federation", 2012).

The same idea is expressed in all the latest Federal State Educational Standards (FSES). For example, the FSES of secondary general education (grades 10-11) (Order of the Ministry of Education of Russia of May 17, 2012 No. 413) states, "The standard is developed taking into account regional, national and ethnocultural needs of the peoples of the Russian Federation and is aimed at ensuring the preservation and development of cultural diversity and the linguistic heritage of the multinational people of the Russian Federation, exercising of their right to study their native languages, and adoption of spiritual values and culture of the multinational people of Russia" (Federal state educational standard of secondary general education, 2019).

FSES of higher education at the level of bachelor's degree (Social Studies) (Order of the Ministry of Education of Russia of February 05, 2018 No. 75) under the General Skills (GS-5) section (Cross-Cultural Interaction) provides for "Ability to perceive the cross-cultural diversity of the society in the social, historical, ethical and philosophical aspects" (Federal state educational standard of higher education, 2019). This means 
that a student, and then a graduate, understands the peculiar features of Russian society as a multi-ethnic and multicultural community and is able to communicate with representatives of different cultures.

What is happening nowadays with the Russian language in reality? What do we hear on the radio, on TV, and what happens to the Russian language on the Internet? The picture is very sad. The speech we hear is illiterate, helpless, littered with vulgarisms and anglicisms, and notably, such language is often heard from people for whom language is the main working tool, such as politicians, TV and radio presenters, and teachers. Not even to mention the Internet. It's no secret that our language is becoming simplified, inexpressive, and clogged with some elements of foreign languages. Sometimes one can feel like a foreigner in the home country. These are well-known facts.

What does education offer us in this respect? There is no single program for learning the Russian language, neither do we have a unified textbook. In some schools, the number of English classes per week is twice or three times the number of Russian classes. At the same time, the school is not responsible for the quality of knowledge the graduates come to life with, because it's main concern is only to report on the results of the unified exam and the number of students who received a hundred points, because it is rewarded financially. The quality of education is constantly declining, the finals have nothing to do with the development of proficiency under the general education curriculum, which treats the language as a system, and, worst of all, the exam does not check the knowledge of the Russian language. After all, it is not only a tool of communication, but also a culture receptacle.

The unified exam itself is a very strange format. For example, the test part of the exam in the Russian language contains only twelve tasks in spelling and punctuation (and this is what is really necessary for life) of the twenty-six in total. The rest of the tasks test general knowledge and skills, such as the ability to summarize the core idea, identify the key and secondary information, answer questions on the text, classify the error type (not correct!), etc. Therefore, the language proficiency level of our graduates is falling dramatically; they are ignorant about the basic rules of spelling and punctuation, unable to speak and formulate their ideas, cannot identify linguistic and speech errors, because all exams, including those at our University, are held in written format.

Basic State Exam in the Russian language (in the 9th grade) looks no more perplexing, since it in principle does not encompass knowledge about the language system and language proficiency, but rather checks random, unrelated topics concerning the sentence structure and only 2(!) topics related to spelling. This year the speaking test was added, which completely follows the pattern of the speaking test of the foreign language exam, such as text reading, retelling, describing a photo, and answering a few questions on the topic. That is, the standards have dropped significantly because all these skills are demonstrated not by a primary school student, which would be quite appropriate, but by a graduate of grade 9 . As a result, students graduate from school, unable to read, write, and speak. This is how they go into adult life and enter colleges and universities.

\section{Results}

The analysis carried out has enabled the authors to identify and formulate the following contradictions in the practice of the Russian language teaching from the soft power policy application standpoint:

First, there are obvious contradictions between the state order requirements, reflected in the regulations, the existing Russian language teaching methodology and the new linguistic existence conditions;

XLinguae, Volume 12, Issue 4, October 2019, ISSN 1337-8384, eISSN 2453-711X 
Second, between the development pace of teaching methodology and modern information and communication technologies;

Third, between the teachers' and students' level of proficiency in modern technologies; Fourth, between the skills that must be developed in students in accordance with the regulatory documents and the lack of a real basis for their application;

Fifth, between the state educational standard focusing on the development of functional literacy in students by means of the Russian language and the lack of standard program documents and textbooks.

The revealed contradictions of modern Russian language teaching help formulate a new topical problem in the context of domestic education modernization, namely, the problem of development of students' general cultural competence in the context of the soft power policy implementation. The aspects of the problem under study are underlain by three levels of knowledge: methodological level, i.e. clarification of the essence of social and cultural factors in the current situation and modernization of Russian education; theoretical level - interpretation of the concepts of "modern linguistic situation" and "soft power" in the context of the theory of Russian language teaching to schoolchildren and students, the identification of linguistic and methodological patterns and principles of teaching Russian language in modern times; methodological level - development and testing of guidelines for the development of general soft skills by means of the Russian language course, the introduction of organizational and methodological system to improve teachers' professional skills.

\subsection{Discussing Various Approaches to the Soft Power Policy Implementation in the Teaching of National Languages}

When it comes to language as a tool of cross-cultural communication, everyone remembers about learning foreign languages. Of course, it is important. In our multiethnic and multicultural country, however, the key role is played by the Russian language as a language of international and cross-cultural communication, the state language, which is used in all communication processes in all spheres of life.

The state policy of soft power aimed to support the Russian language as a language of cross-cultural communication is of particular importance. The Fundamental Principles of State Cultural Policy declare "the improvement of the level of Russian citizens' proficiency in the Russian language", and one of the cultural policy objectives is proclaimed to be "the promotion of the Russian language in the world, support and promotion of Russian-speaking communities' expansion in foreign countries, raising the interest towards the Russian language and Russian culture in all countries of the world" (Basics of the state cultural policy, 2019).

The education law, as last amended in 2018 singled out the priority of studying the Russian language and literature, which manifests itself through such large-scale events as, for example, Total Dictation (Russian Spell Well) covering all regions of Russia.

Many states are making efforts to develop comprehensive measures to preserve the national language (Zeiter, 2019). The most striking and illustrative example of this can be the policy of France, a country making considerable efforts to preserve its language domestically and expand its influence beyond its borders. Today, France has developed a well-elaborated, comprehensive action plan aimed to address the problems of language presence in the country and abroad, along with countering the influence of the English language. The government exercises general control over these activities, as well as the entire foreign cultural policy, through the system of ministries and state agencies, but in practice, they are most often implemented through other mechanisms, such as French Alliance (Alliance Francaise), cultural centers and various educational programs. French language policy pursues two main objectives: first, maintaining the position of the French language and its promotion abroad, and, second, its protection from external linguistic influences at the national 
level, in particular, from the influence of the English language, and in recent years, from the Arabic language as well (Shaydenko, Kutepov, 2016).

In recent years, on the back of Arab migrants flooding into France, there has been considerable public debate on the inclusion of Arabic as an optional language in the school curriculum. However, this proposal has both supporters and many opponents in the country. The proponents say French legislation provides for the protection of regional languages, among which they consider also Arabic. However, their opponents insist that the official language in France is only French, and the deviation from this rule will be a significant concession to the Arab diaspora.

What about Russia? It will be recalled that Russia was originally formed as a multinational state, in which Russian has always been the language of cross-cultural and cross-ethnical communication. Language as a tool and culture receptacle. Language has numerous functions; it forms the personality of an individual, a native speaker; it is the most important tool of communication and a critical factor of integration. Language is also an instrument of ethnic self-preservation. However, language is not only a tool, which determines cross-cultural communication, but also the environment in which a person functions, simultaneously falling under its influence. Language reflects the people's idea about its place in the world, a complex hierarchy of social and political relations, as well as future aspirations.

When it comes to the linguistic aspect of cross-cultural communication, we must remember that languages themselves need protection and support, since, being the code of culture, they store unique information passed down from generation to generation, which must be preserved for descendants (Mackenzie, 2018). The diversity of cultures in the world largely depends on linguistic diversity, which reflects many cultural traditions. It is no coincidence that so much attention is paid in the modern world to the preservation of language and its spread as a means of successful and deep cultural communication, which is reflected also in the legislative practice of various states, as well as in the activities of authoritative international organizations (Raff, 2012). But it is important to understand that we are talking not only and not so much about the preservation of the languages of the so-called small ethnic groups, but also about the preservation of the state language, i.e., the language of cross-cultural communication.

\section{Conclusions}

In the modern global world, competition is acquiring cultural and civilizational dimensions. Russia's foreign policy proceeds from the fact that "the struggle for cultural influence is intensifying between the main players in the international arena, with the increasing involvement of new centers of power emerging in the world" (Torkunov, 2012).

The crisis situation currently observed can be overcome through a developed education system, which meets the requirements of an innovative high-tech economy, is integrated into the international educational and academic community, and is able to become one of the most important competitive advantages of modern Russia in the "global struggle for minds" (Torkunov, 2012).

Specific actions to overcome the crisis would be the steps towards developing a modern system of the Russian language teaching through the use of the soft power policy: modernization of the methodical system of the Russian language teaching, since today it does not take into account such processes as intensive democratization of the language and the virtuality of modern communications; due account of the factors hindering education and development of students, such as intense language processes, the influence of mass culture on the emergence of a new language, the intensive language transformation; sustainable passion of young people for 
information and communication technologies; and teachers' passive attitude to their own computer and information literacy.

\section{Acknowledgments}

1.The work is performed according to the Program of Development of Financial University under the Government of the Russian Federation for 2020.

2. The work is performed according to the project of improving the competitiveness of the leading Russian universities among the leading world scientific education centers "5-100"of First Moscow State Medical University.

3. The publication has been prepared with the support of the "RUDN University Program 5-100".

4.The work is performed according to the Russian Government Program of Competitive Growth of Kazan Federal University.

\section{Bibliographic references}

AREFYEV, A.L. 2017. The current state and trends of the spread of the Russian language in the world. Scientific publication. Moscow: ISPI RAS. ISBN 978-5906001-67-2.

BAKHTIN, M.M. 1986. Aesthetics of verbal creativity. Moscow: Art.

BASICS OF THE STATE CULTURAL POLICY. 2019. Available online: http. static.kremlin.ru / media / events / files / 41d526a87768a8730eb.pdf

BIBLER, V.S. 1986. Culture Dialogue of cultures (experience of definition). In: Questions of Philosophy, vol. 6, pp. 31-42. ISSN 0042-8744.

BOVT, G. 2019. Soft power of the Russian word. Available online: https://russiancouncil.ru/analytics-and-comments/analytics/myagkaya-sila-russkogo-

slova/

FEDERAL LAW “ON EDUCATION IN THE RUSSIAN FEDERATION”. 2012. dated December 29, 2012 No. 273-FZ. Available online: http://zakon-obobrazovanii.ru/

FEDERAL STATE EDUCATIONAL STANDARD OF HIGHER EDUCATION. 2019. Available online: https://fgos.ru/

FEDERAL STATE EDUCATIONAL STANDARD OF SECONDARY GENERAL EDUCATION. 2019, Available online: https://fgos.ru/

FILIMONOV, G.Yu. 2012. Actual issues of the formation of the Russian potential of "soft power". In: Vestnik RUDN. Series: Political Science, n. 1, pp. 67-82. ISSN 2313-1438

GENG, X. 2017. The Influence of Teachers' Language on Middle Students' Psychology. In: Eurasia Journal of Mathematics, Science and Technology Education, vol. 13, n. 8, pp. 5637-5644. ISSN: 1305-8215.

GONULAL, T. 2019. The use of Instagram as a mobile-assisted language learning tool. In: Contemporary Educational Technology, Vol. 10, n. 3, pp. 309-323. ISSN: 1309-517X.

GORLOVA, I.I. - BYCHKOVA, O.I. 2019. Culture as "soft power: tools and points of application. Available online: http://teoriapractica.ru/rus/files/arhiv_zhurnala/2015/18/cultur-e/gorlova-bychkova.pdf

HALL, E.T. 1989. Beyond Culture. New York: Anchor Books. - ISBN 9780385124744

KAMALOVA, L.A. - ZAKIROVA, V.G. 2017. Developing the Methodology for Effective Teaching of the Russian Language to Migrant Muslim Children. In: Eurasia Journal of Mathematics, Science and Technology Education, vol. 13, n. 12, pp. 78137821. ISSN: 1305-8215.

KOLODEZNIKOV, S.K. - KOLODEZNIKOVA, L.D. 2016. Specificity of teaching Sakha as an official language in the Russian-language schools of Yakutia. In: 
International Electronic Journal of Mathematics Education, vol. 11, n. 10, pp. 3477 3485. ISSN 1306-3030.

KORKMAZ, S. - GUNEYLI, A. 2017. Impact of Technology-Assisted ContextBased Teaching on the Listening Skills of Teacher Candidates. In: Eurasia Journal of Mathematics, Science and Technology Education, vol. 13, n. 8, pp. 4669-4677. https://doi.org/10.12973/eurasia.2017.00957a, ISSN:1305-8215.

KUZINA, E.S. 2018. Education and the modern stage of the scientific and technological revolution. Materials of the International Interdisciplinary Scientific Practical Conference. Kazan: Publisher: Fatherland. ISBN 978-5-9222-1244-1

LEBEDEVA, M.M. 2017. "Soft power": the concept and approaches. In: Bulletin of MGIMO-University, vol. 3, n. 54, pp. 212-223. ISSN 2071-8160

LOTMAN, Yu.M. 1998. About art. St. Petersburg: Art-SPB. ISBN 5-210-01523-8.

MACKENZIE, I. 2018. Language Contact and the Future of English. London: Routledge. ISBN: 1138557226

NIKIFOROVA, E.P. - IGNATIEV, V.P. 2016. Issues of Professional Training for Russian Language Teachers in the Conditions of a Multicultural Environment. In: International Electronic Journal of Mathematics Education, vol. 11, n. 10, pp. 34253433. ISSN 1306-3030.

NYE, S.J. 2004. Soft power. The Means to Success in World Politics. New York: Public Affairs. ISBN 1586482254; 1586483064.

POHLER, B. - GEORGE, A.C. - PREDIGER, S. - WEINERT, H. 2017. Are Word Problems Really More Difficult for Students with Low Language Proficiency? Investigating Percent Items in Different Formats and Types. In: International Electronic Journal of Mathematics Education, vol. 12, n. 3, pp. 667-687. ISSN 13063030.

RAFF D. 2012. What is the evidence for the impact of National Qualifications Frameworks? In: Comparative Education, vol. 49, n. 2, pp. 143-162. Available online: http://www.tandfonline.com/doi/full/10.1080/03050068.2012.686260

RUSAKOVA, O.F. - NOSOVA, T.N. 2015. Russian strategic model Softpower. In: Scientific journal "Discourse-Pi", vol. 1, n. 12, pp. 148-152. ISSN 1817-9568

SHAYDENKO, N.A. - KUTEPOV, S.N. 2016. National priorities of vocational education and training in the context of European integration: the experience of France. In: Domestic and foreign pedagogy, vol. 1, n. 28, pp. 100-110. ISSN 22240772

SIMSEK, A. - ELCIYAR, K. - KIZILHAN, T. 2019. A Comparative Study on Social Media Addiction of High School and University Students. In: Contemporary Educational Technology, Vol. 10, n. 2, pp. 106-119. ISSN: 1309-517X.

SUM, E. - KWON, O.N. 2018. An Analysis of Linguistic Features of the Multiplication Tables and the Language of Multiplication. In: Eurasia Journal of Mathematics, Science and Technology Education, vol. 14, n. 7, pp. 2839-2856. https://doi.org/10.29333/ejmste/90760, ISSN:1305-8215.

TORKUNOV, A.V. 2012. Education as a tool of "Soft power" in Russian foreign policy. In: Bulletin of MGIMO, n. 4, pp.85-93. ISSN 2071-8160

UZUN, K. 2018. Home-Grown Automated Essay Scoring in the Literature Classroom: A Solution for Managing the Crowd? In: Contemporary Educational Technology, Vol. 9, n. 4, pp. 423-436. ISSN: 1309-517X.

YASHKOVA, T.A. 2015. BRICS as an option of soft power. Available online: http://cyberleninka.ru/article/n/briks-kak-vari-ant-myagkoy-sily

ZEITER, A-C. 2019. Francophone Canadian, franco - mobile, Tamil? Unfolding identity. In: Journal of Sociolinguistics, vol. 23, n. 1, pp.82-96. ISSN 1467-9841.

Words: 5187

Characters: 35650 (19,81 standard pages)

XLinguae, Volume 12, Issue 4, October 2019, ISSN 1337-8384, eISSN 2453-711X 
Natalia A. Orekhovskaya, Dr.

Department of Sociology, History and Philosophy

Financial University under the Government of the Russian Federation

49 Leningradsky Prospect

125993, Moscow

Russia

orehovskaya@yandex.ru

Elena I. Zamaraeva, PhD.

Department of Sociology, History and Philosophy

Financial University under the Government of the Russian Federation

49 Leningradsky Prospect

125993, Moscow

Russia

zamaraeva_e@mail.ru

prof. Evgeniya V. Shikh, Dr.

Department of Clinical Pharmacology and Propedeutics of Internal Diseases

I.M. Sechenov First Moscow State Medical University (Sechenov University)

8 Trubetskaya Street

119991, Moscow

Russia

chih@mail.ru

prof. Alexander A. Galushkin, PhD.

1) Director of the Scientific and Educational Center "Legal Research"

Peoples' Friendship University of Russia (RUDN University)

Miklukho-Maklaya Str. 6

117198, Moscow

2) Head of the Laboratory of Economics and National Economy Management Stolypin International Institute of Informatization and Public Administration 11/2 Malaya Semyonovskaya Str.

107023, Moscow

Russia

alexander.galushkin@yandex.ru

prof. Raisa I. Platonova, Dr.

Faculty of Road Construction

North-Eastern Federal University named after M.K. Ammosov

58 Belinskogo Street

677000, Yakutsk

Russia

platonova_raisa@mail.ru

assoc. prof. Alfia M. Ishmuradova, $\mathrm{PhD}$.

Department of Foreign Languages

Kazan (Volga region) Federal University

18 Kremlyovskaya Street

420008, Kazan

Russia

alfiaishmuradova@mail.ru 